\title{
Assessment of water and sanitation systems at Palestinian healthcare facilities: pre- and post-COVID-19
}

\author{
Fathi Anayah (D) - Issam A. Al-Khatib (i) • Banan Hejaz
}

Received: 30 August 2020 / Accepted: 7 December 2020 / Published online: 7 January 2021

(C) The Author(s), under exclusive licence to Springer Nature Switzerland AG part of Springer Nature 2021

\begin{abstract}
The availability of safe drinking water and the proper management of wastewater in healthcare facilities are important pillars for maintaining safety of workers, patients, and visitors and protecting human health and environment. Water and sanitation services at 495 healthcare facilities in the West Bank of Palestine are assessed using the results of PCBS and MoH (2014) survey study. Services are reassessed after the COVID10 pandemic using personal interviews with experts from healthcare facilities, regulatory authorities, and service providers. The results show that $92.1 \%$ of healthcare facilities were connected to public water networks, $12.9 \%$ of them purchased water tanks, and $10.8 \%$ of them depended on harvested rainwater which may cause contamination and waterborne diseases. Regardless the source of freshwater, the water quality has to be regularly examined and compared to local guidelines and international standards for health promotion. Almost $63.4 \%$ of healthcare facilities were not connected to wastewater networks and used either tight or
\end{abstract}

F. Anayah

Faculty of Engineering and Technology, Palestine Technical

University - Kadoorie, P. O. Box 7, Tulkarm, Palestine

I. A. Al-Khatib ( $\bowtie)$

Institute of Environmental and Water Studies, Birzeit University, P. O. Box 14, Birzeit, Palestine

e-mail: ikhatib@birzeit.edu

e-mail: ikhatib2012@yahoo.com

B. Hejaz

Universal Institute of Applied \& Health Research, Nablus,

Palestine porous cesspits. Once these cesspits are filled off, wastewater is randomly disposed into nearby valleys causing adverse environmental impacts on air, water, and land resources. Medical wastewater of hazardous substances should be treated before discharged to wastewater networks. Experts assured that although heightened procedures have been made by service providers to curb the spread of the COVID-19 disease, yet, more consistent protocols and stringent procedures are crucial. There have not been any new directives or procedures regarding the management of water supplies and wastewater services in the healthcare facilities. Stakeholder collaboration can help prevent the COVID-19 disease.

Keywords Water - Wastewater Healthcare facility . Management $\cdot$ West Bank

\section{Introduction}

Water is indispensable for life and particularly significant in the healthcare field, starting from cleaning to hydrotherapy. Water also plays an important role for domestic uses in restrooms such as using showerheads, toilets, and sinks, as well as in kitchens especially for drinking cooking, dishwashing, and personal hygiene (Yadav et al. 2017; Khan et al. 2019). Sampling and monitoring the water system in healthcare facilities are of great importance so that adequate quality of water is maintained for the different water uses. Health promotion and disease prevention entail the provision of proper water 
and sanitation services as well as the best hygiene practices in healthcare facilities.

Within the distance from tap to sink, most water used becomes wastewater. Typically, generated wastewater represents a considerable portion of consumed water (see PCBS 2002; World Bank 2018). Unlike domestic wastewater, the discharge of healthcare wastewater might include pharmaceutical complexes, antibiotics, narcosis, radioactive elements, pathogens, and other hazardous compounds (Khan et al. 2019; WHO and UNICEF 2019). In addition, several microorganisms exist in medical wastewater which are resistant to antibiotics and can cause severe illnesses to humans (Khan et al. 2020).

Healthcare wastewater is originated from different sources such as hospitals, dialysis centers, medical laboratories, medical and dental clinics, pharmacies, medical research centers, and diagnostic laboratories and radiology. Medical activities such as immunization programs, diagnosis and treatment, experiments in health research centers, and examinations in medical laboratories at healthcare facilities might create huge amounts of hazardous wastes in addition to enormous quantities of domestic wastes. This issue is becoming larger with every new hospital, clinic, or diagnostic laboratory setting up (Bokhoree et al. 2014). Healthcare wastewater management is fundamental because it has a large impact on public health and the environment (see WHO and UNICEF 2019).

Therefore, the Palestinian Central Bureau of Statistics (PCBS) and the Ministry of Health (MoH) (2014) had jointly conducted a comprehensive survey study of all Palestinian healthcare facilities including governmental and non-governmental facilities. The PCBS and $\mathrm{MoH}$ (2014) offered statistical data and information regarding water uses and characteristics, wastewater disposal methods, and several environmental impacts. The $\mathrm{MoH}$ had frequently published a variety of statistics and indicators to describe the health situation in Palestine (see MoH 2013, 2017, 2019) and adopted a national strategy to improve services in all healthcare facilities (see $\mathrm{MoH}$ 2016). Other local studies (e.g., PCBS 2012; UNDP 2014; ARIJ 2015; World Bank 2018) were useful to understand the current status of the healthcare facilities and how these facilities manage water and wastewater services. International studies of interest (e.g., WHO 2015, 2017a, 2017b; WHO and UNICEF 2018) were important to compare results and findings with healthcare facilities in the world, in particular similar countries.

Although public healthcare services are available and affordable to almost all population segments $(\mathrm{MoH}$
2019), the demand of rich and poor Palestinians for expensive services in the private sector is high (SHOPS Plus 2018). Public healthcare institutions offer inefficient, inadequate, and inequitable services (Pfeiffer 2001; UNDP 2014) and focus on qualification and experience of the healthcare workforce cadres, but not their performance (SHOPS Plus 2018). In 2018, the numbers of primary healthcare facilities and hospitals (i.e., secondary healthcare facilities) in the West Bank had been 732 and 82, respectively (MoH 2019). There were 498,179 hospital treatment days in 2016, while there were 581,713 visits to outpatient clinics in the West Bank (MoH 2017). The Palestinian healthcare system is currently under pressure and the services provided are to be overwhelmed by COVID-19 soon.

It is believed that water and wastewater services in healthcare facilities should be managed differently after the onset of the COVID-19 virus in a developing country with limited technical and financial resources such as Palestine. The novel coronavirus has been detected in the wastewater (Bar Or et al. 2020; Farkas et al. 2020; Weidhaas et al. In review), yet less attention has been paid to the virus migration to water systems (see Bhowmick et al. 2020; Paleologos et al. 2020). Wastewater epidemiology has been globally used to collect sewage characteristics, monitor infectious disease spread, assess fate and transport of pathogens, control the spread of pandemics (Paleologos et al. 2020), determine public health response, and serve as an early warning of outbreaks (Bar Or et al. 2020; Bhowmick et al. 2020; Weidhaas et al. In review). Understanding the characteristics of the novel coronavirus including favored environments and transmission pathways becomes more important to resist its eruption (see Azzi et al. 2020; Bhowmick et al. 2020; Wang et al. 2020; Xiao et al. 2020). As a result, water and wastewater services need to be frequently examined to reduce the possibility of the COVID-19 spread.

In effect, the water and wastewater services at healthcare facilities are more vulnerable to serve as channels for the disease to spread through. We should keep an eye on this important issue and inspect if people recognize associated risks. The survey study, i.e., PCBS and $\mathrm{MoH}$ (2014), had been the last one to conduct in Palestine, and therefore, it is considered as the existing condition of the services at healthcare facilities. The experts assured that the progress in the health system which took place in the last few years was not that significant. Therefore, the existing condition is 
represented as the pre-COVID-19 status, while the socalled new condition proposed to tackle the new comer is called the post-COVID-19 status. The results of the present study are presented at a regional level: north, middle, and south of the West Bank. The analysis and discussion of the results include freshwater sources and quantities consumed, wastewater disposal methods, and wastewater treatment techniques before and after the onset of the novel coronavirus pandemic. In this study, a comprehensive approach is used to review and evaluate water supplies and sanitation services at the health system in the West Bank of Palestine. The present paper includes the study and assessment of water and wastewater systems in the healthcare facilities of the study area. It is also aimed to re-evaluate the water and sanitation systems in view of the novel coronavirus pandemic. The current conditions of the water and sanitation services at healthcare facilities are assessed using the questionnaire; however, the interviews are conducted to investigate changes made to the services provided during the novel coronavirus pandemic and make a comprehensive assessment to these services.

\section{Methodology and study area}

The healthcare system in the West Bank consists of five providers: the $\mathrm{MoH}$, the United Nations Relief and Works Agency (UNRWA), the non-governmental organizations (NGOs), the military medical services, and the private sector (Pfeiffer 2001; SHOPS Plus 2018; $\mathrm{MoH}$ 2019). These five providers offer primary, secondary, and tertiary healthcare services to the Palestinians. The major providers are the $\mathrm{MoH}$ and UNRWA for primary healthcare services, the MoH and NGOs for secondary healthcare services, and the private sector for the tertiary healthcare services (Pfeiffer 2001).

Data used in this article were acquired from the "Environmental survey for health care facilities (governmental and non-governmental)" study, conducted by the PCBS and the MoH in the West Bank of Palestine (PCBS and MoH 2014). The survey study of PCBS and $\mathrm{MoH}$ (2014) covered the vast majority of the healthcare facilities in the West Bank which were 495 facilities distributed as follows: 223 facilities in the north of the West Bank, 93 facilities in the middle of the West Bank, 179 facilities in the south of the West Bank. It is worth to mention that the PCBS and MoH (2014) study covered another 97 and 38 healthcare facilities in Gaza Strip and
Jerusalem district, respectively, yet these facilities were not included in the present study. The management system of the health sector in the West Bank is significantly dissimilar at Jerusalem and Gaza Strip. Therefore, the criteria to evaluate the performance of the system should also be different.

Qualitative and quantitative data were collected from a wide number of healthcare facilities in the research region using questionnaires prepared and collected by PCBS and MoH (2014) joint team. This part displays the empirical approach applied during the design and accomplishment of the environmental study for healthcare facilities through the survey tools, practical collection, and data analysis. The environmental survey prepared takes in consideration both the international standards and the local conditions of the Palestinian community (see PCBS and MoH 2014).

Here are the steps used to design the questionnaire: (1) checking all references that are pertinent to the United Nations' and World Health Organization' recommendations (e.g., UN 1997; WHO 2015, 2017a, 2017b; WHO and UNICEF 2018), (2) studying the survey applied by the Palestinian MoH (e.g., MoH 2013, 2017, 2019), and (3) reviewing the past PCBS environmental questionnaires including the domestic, economic, and educational sections (see PCBS 2002, 2012; PCBS and MoH 2014). The questionnaire of PCBS and $\mathrm{MoH}$ (2014) was revised and updated according to the major findings of the environmental questionnaires for healthcare facilities in the PCBS (2012) study.

All healthcare facilities, governmental and non-governmental, are the target population of the study. The governmental healthcare facilities included belong to the $\mathrm{MoH}$, Health Care Military Services, and Lijan Az-Zakah (charitable institutions). As for the non-governmental healthcare facilities, the Health Union Committees, Union of Palestine Health Care Relief Committees, Patients Friends Benevolent Society, UNRWA, Palestine Red Crescent Society, and Red Cross are considered in this study. The private healthcare sector was not covered in the PCBS and MoH (2014) survey study.

The questionnaire contains a cover page with some information about the healthcare facility, external environmental factors, and water and wastewater management. The field work was conducted during the period from March 2014 to September 2014 with a response rate from the target group of $80 \%$ (PCBS and $\mathrm{MoH}$ 2014). The questionnaires were edited prior to data entry and the inherent uncertainties of data due to sampling 
and non-sampling errors were minimized using multiple statistical methods (PCBS and MoH 2014). Inputting Data using Microsoft Access enables researchers conduct further processing and analysis using statistical packages such as SAS and SPSS (see PCBS and MoH 2014). It is noteworthy to mention that the data of the questionnaires are presented by region.

The other research instrument used for this study is to interview medical administrators from the healthcare facilities in the West Bank about the COVID-19 virus and how these facilities react with the new comer to negate its effects on the workers, patients, and visitors. Again, all healthcare facilities, governmental and non-governmental, are targeted in the interview study. In addition, the interviews include administrative directors/officers in the governmental regulatory authorities as well as a few service providers involved in the water and wastewater sectors of the West Bank. The in-person interviews with the experts are conducted in August 2020 and have been replaced by telephone interviews when direct interviews are not possible.

A well-structured list of questions and queries in the research interviews was prepared and the responses from the interviewees were recorded and summarized in the present study. The institutional or organizational views and information gathered from professional interviewees were documented no matter the personal perspectives they have. There is still a room for the interviewees to present their personal views and suggestions to improve services provided by the health system to the local community.

The study area is the West Bank which consists of 11 districts (see Fig. 1). The northern districts consist of

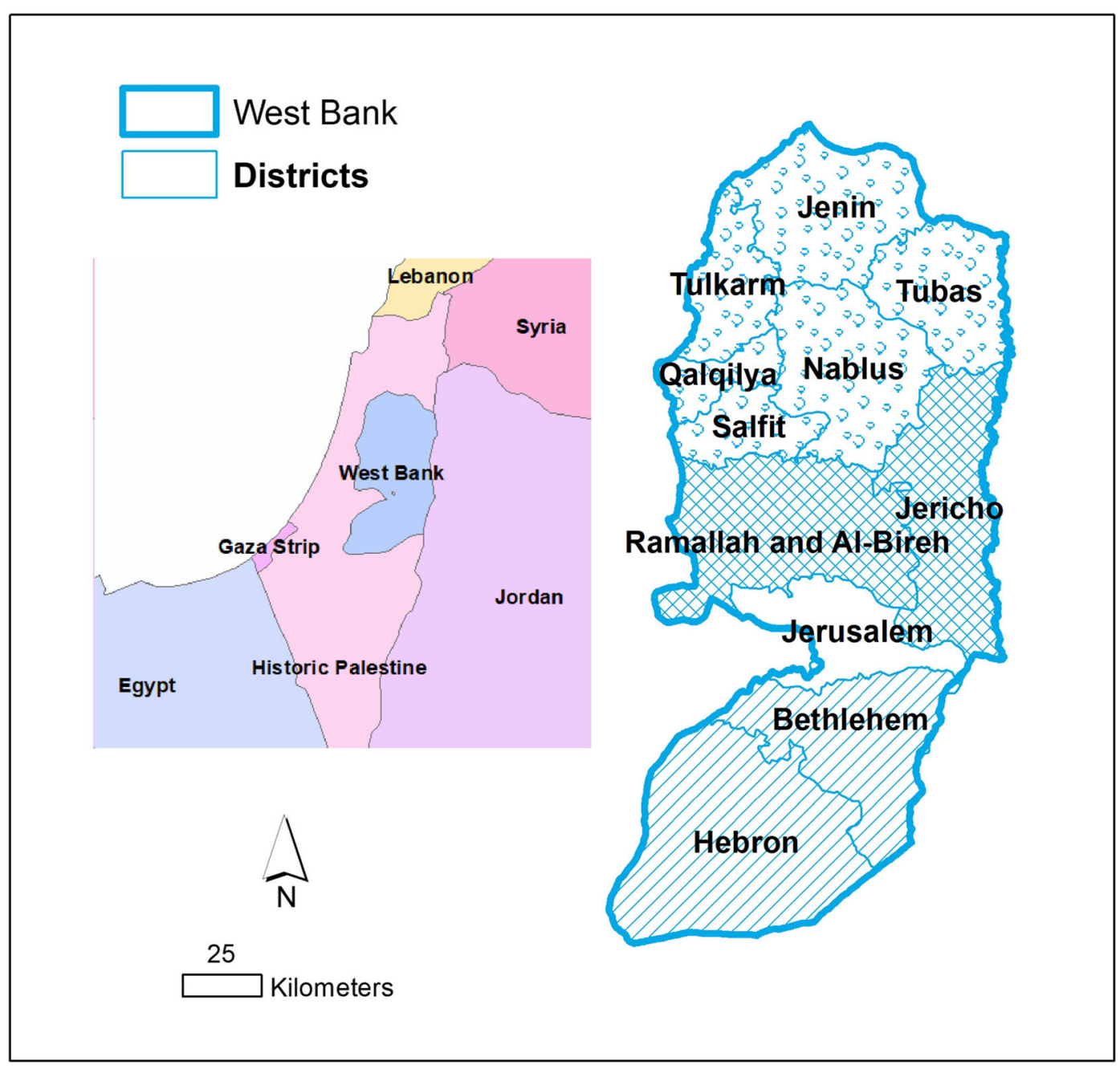

Fig. 1 The West Bank districts of Palestine 
Jenin, Tubas, Nablus, Tulkarm, Qalqilya, and Salfit. The Jericho and Ramallah and Al-Bireh districts lie in the middle of the West Bank. The south of the West Bank has Bethlehem and Hebron districts. There are 594,429 households of an average size of 4.8 (PCBS 2018) living in 734 communities in the West Bank (ARIJ 2015). The West Bank is highly populated and houses almost 2.9 million Palestinians of which $51 \%$ are males and $66 \%$ have health insurance coverage (PCBS 2018). The West Bank has area of $5800 \mathrm{~km}^{2}$, a length of $130 \mathrm{~km}$ from north to south, and a width of 40 to $65 \mathrm{~km}$ from east to west (Anayah and Almasri 2009). The elevation varies from $400 \mathrm{~m}$ below sea level in the Dead Sea to $1022 \mathrm{~m}$ above sea level at the Tall Asur, while most West Bank mountains are $800 \mathrm{~m}$ high (ARIJ 2015).

The Mediterranean climate which prevails in the West Bank (PWA 2013b; ARIJ 2015) with hot, dry summers and cool, and wet winters (Anayah 2006). The aridity increases in the south eastern areas due to high evaporation rates, particularly in the summer season (Anayah and Almasri 2009). The average rainfall significantly varies from $100 \mathrm{~mm} / \mathrm{year}$ in the Jordan Valley to $700 \mathrm{~mm} /$ year in the central mountains of the West Bank (PWA 2013b). The average monthly temperature varies between 8.7 and $30{ }^{\circ} \mathrm{C}$ and the relative humidity ranges from 50 to $70 \%$ in the West Bank (ARIJ 2015). Such climatic variables may significantly affect water quality and contaminate water supplies (see Alazzeh et al. 2019).

The groundwater, springs, and harvested rainwater are the three major sources of freshwater in Palestine (PWA 2013b, 2018; ARIJ 2015). Palestinians living in the West Bank consumed 163.1 million cubic meter of freshwater in 2013 (ARIJ 2015). Most Palestinian areas are highly populated and blessed with agricultural resources (ARIJ 2015; PCBS 2018).

For each 100,000 of the Palestinian population in 2018, there were 215 physicians, 71 dentists, 112 pharmacists, 236 nurses, and 23 midwives (MoH 2019) which sum to 657 . The figures of 2018 are not close to those in the previous studies of $\mathrm{MoH}$. The numbers of health workforce cadres were 575 and 612 in the years 2012 and 2016, respectively (MoH 2013, 2017). Compared to the benchmark of 450 workforce per 100,000 population in 22 east Mediterranean countries, Palestine did always stand above the average number of the health workforce cadres in primary healthcare facilities in 2015 (WHO 2018).
Since the year 2000, almost $90 \%$ of the people live close to a healthcare facility within $5 \mathrm{~km}$ to their residence (Pfeiffer 2001) and residents are even better off now. Therefore, let us focus a little more on primary healthcare facilities distributed all over the West Bank. In 2018, there were 732 primary healthcare facilities in Palestine, of which $63.9 \%$ belong to $\mathrm{MoH}, 24.9 \%$ belong to the NGOs, $8.9 \%$ belong to the UNRWA, and $2.3 \%$ belong to the military medical facilities $(\mathrm{MoH}$ 2019). The status of primary healthcare facilities in Palestine has been deeply compared to 22 countries in the WHO region of eastern Mediterranean from Morocco to Pakistan in the WHO (2018) report.

In the West Bank, the total numbers of visits to physicians and nurses in the primary healthcare facilities of the West Bank in 2018 were 2,395,279 and 2,395,513, respectively ( $\mathrm{MoH} 2019$ ). As declared by the Palestinian national health strategy (MoH 2016), an important indicator to monitor quality health services is the number of people served by each primary healthcare facility. In effect, the demographic distribution of primary healthcare facilities in each district of the West Bank is described in Fig. 2.

Among all districts of the West Bank, there are 4506 persons for each primary healthcare facility in 2018 (MoH 2019), on average, and this figure is lower (as low as one-fourth) than that of many other developing countries (see WHO 2017a). While Jerusalem district is noticed to have the lowest population rate of people served by each primary healthcare facility, Nablus has the highest rate and requires an in-depth analysis and recommendations such as suggesting a larger coverage rate of healthcare services in the foreseeable future.

\section{Results and discussion}

There are several challenges and limitations that prevent any sustainable development to the Palestinian water and wastewater sectors since Israel controls all natural resources (PWA 2013a; UNESCWA 2020). These challenges and limitations have political, financial, technical, institutional, social, and environmental dimensions (PWA 2013a; ARIJ 2015). The efficiency of water and wastewater systems is more important for healthcare utilities because hygiene and sanitation are of the highest priority. 


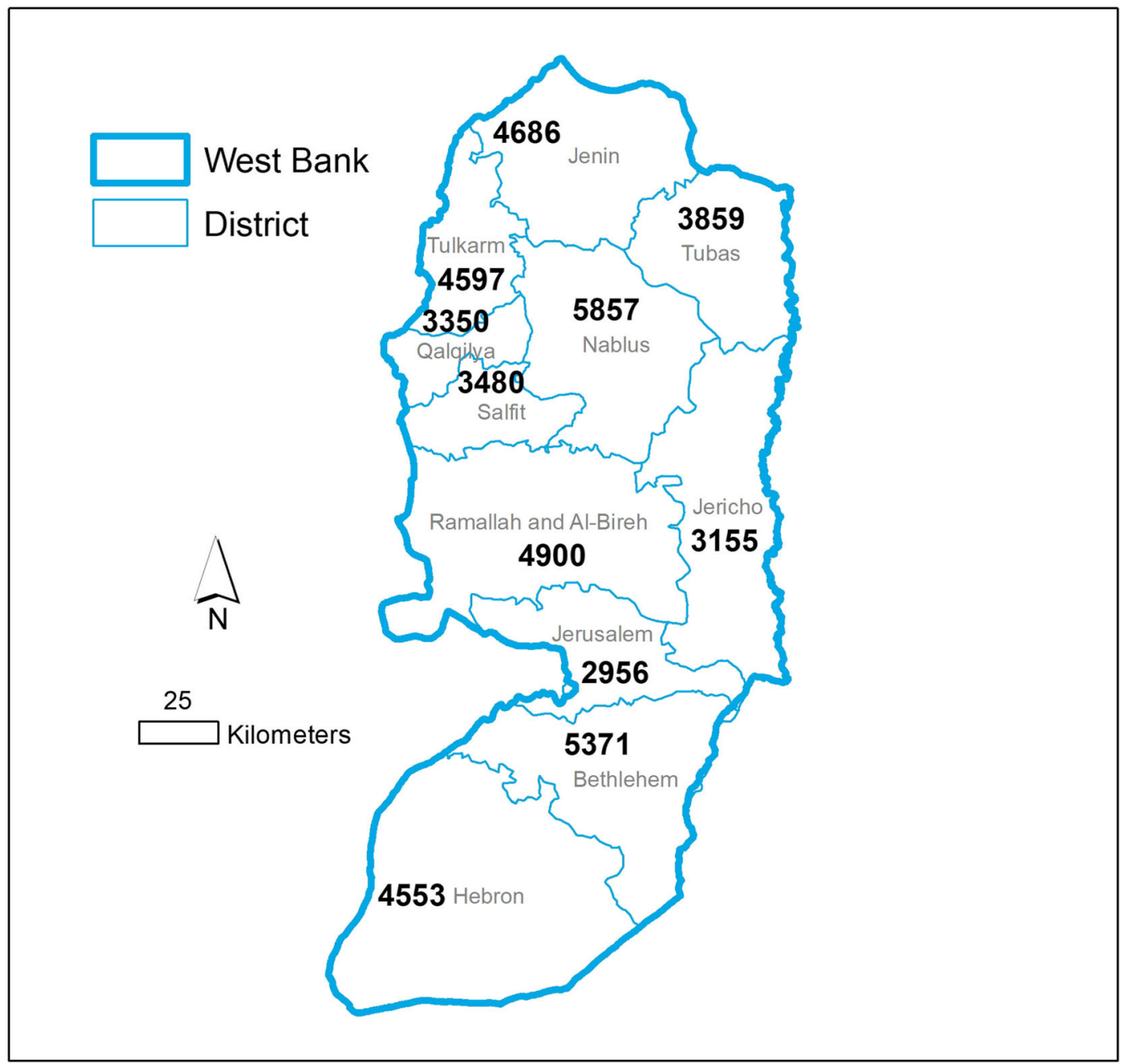

Fig. 2 The demographic distribution of primary healthcare facilities in 2018 in the West Bank districts in persons per facility (Source of data: $\mathrm{MoH} 2019$ )

Water consumption and origins of supply

Palestine has three main freshwater sources: the Jordan River, the West Bank aquifers, and the Coastal aquifer (ARIJ 2015). The mountain aquifer of the West Bank consists of the western, the eastern, and the northeastern aquifer basins (PWA 2013b, 2018; ARIJ 2015). The western aquifer discharges into the Mediterranean Sea, the eastern aquifer discharges into the Jordan River, and the northeastern aquifer discharges into both water bodies (PWA 2013b, 2018).

The Palestinians confront water, public health, and environmental challenges due to the political constraints imposed by the Israelis (PWA 2013a; ARIJ 2015). Since 1967, Israel not only controls all water resources including surface and groundwater, but also it utilizes 85\% of these resources (PWA 2013b; ARIJ 2015). Hence, groundwater is the major water source through a large number of wells and springs distributed all over the Palestinian districts (Anayah and Almasri 2009) and almost fully controlled by Israel (Amnesty International 2009; PWA 2013a, 2018; ARIJ 2015). In areas where local groundwater resources are scarce or access to them is denied (Amnesty International 2009), water is purchased from Israel's water company (PWA 2013b; ARIJ 2015).

In the West Bank, water is mainly delivered by the West Bank Water Department and the Palestinian Water Authority (PWA) is the lead agent of the sector that outlines strategies and develops policies (PWA 2018). 
The Water Sector Regulatory Council (WSRC) monitors the quality and efficiency of the water and wastewater services provided to customers (WSRC 2019). Water service utilities including local, municipal, and regional entities are responsible for supplying drinking water to the Palestinian communities, maintaining water network infrastructure, and collecting water bills (ARIJ 2015).

In the West Bank, the average water supply for Palestinians in 2013 was 110 l/capita/day, yet, the average actual consumption rate was only $79 \mathrm{l} /$ capita/day (PWA 2014) due to the high water losses (UNDP 2014; ARIJ 2015; World Bank 2018). The rate is below the WHO minimum standard of water consumption (Amnesty International 2009; World Bank 2018). Palestinians confront tremendous challenges in the quality and quantity of water supplies in the West Bank (see Anayah and Almasri 2009; PWA 2013b, 2018; UNDP 2014; ARIJ 2015; World Bank 2018). In 2016, 11,980 water samples were tested in the West Bank of which $14.7 \%$ of the samples were contaminated ( $\mathrm{MoH} 2017)$. Out of the 12,394 water samples tested in 2018, 13.3\% were contaminated in the West Bank (MoH 2019). Water supplies still require further surveillance and attention from competent authorities.

In public buildings, water is typically needed in landscape watering, cooling and heating, and restrooms. In healthcare facilities, water is mainly used for sterilization of medical tools using disinfectants that cannot be prepared with no water (Ajo et al. 2018). In hospitals, for instance, water is consumed in several units like inpatient suites, surgical compartment, laboratories, kitchens, health duties, and managerial units. Once water is used, its chemical, physical, and biological goodness deteriorate and water is turned into wastewater (Szekeres et al. 2017).

In the PCBS (2012) survey study, it is noticed that the percentage distribution of the different sources of freshwater added up to $100 \%$ for every region (see Table 1). To be more precise, it means that the percentage distribution is for the "main" source of freshwater at the healthcare facility. In the PCBS and MoH (2014) survey study, however, the percentage distribution of the different sources of freshwater exceeded $100 \%$, for each region. This means that there could have been multiple freshwater supplies at the healthcare facility, especially in the southern districts where water resources are scarce. There is no argument that water needs in the summer increase while water supplies diminish. While
Table 1 Percentage distribution of healthcare facilities in Palestine by source of freshwater and region in the a. year 2014 and b. year 2012

\begin{tabular}{|c|c|c|c|c|}
\hline \multirow[t]{2}{*}{ Region } & \multicolumn{4}{|c|}{ Source of freshwater $(\%)$} \\
\hline & $\begin{array}{l}\text { Water } \\
\text { network }\end{array}$ & $\begin{array}{l}\text { Harvested } \\
\text { rainwater } \\
\text { well }\end{array}$ & $\begin{array}{l}\text { Water } \\
\text { tanks }\end{array}$ & Others \\
\hline \multicolumn{5}{|c|}{ a. Year 2014 (PCBS and MoH 2014) } \\
\hline Palestine & 93.0 & 9.8 & 14.9 & 1.4 \\
\hline West Bank & 92.1 & 10.8 & 12.9 & 1.0 \\
\hline $\begin{array}{l}\text { North of West } \\
\text { Bank }\end{array}$ & 94.8 & 9.9 & 4.0 & 0.0 \\
\hline $\begin{array}{l}\text { Middle of West } \\
\text { Bank }\end{array}$ & 99.1 & 10.9 & 5.9 & 0.9 \\
\hline $\begin{array}{l}\text { South of West } \\
\text { Bank } \\
\text { b. Year } 2012(\mathrm{PC}\end{array}$ & $\begin{array}{l}83.5 \\
2012)\end{array}$ & 11.8 & 29.2 & 2.4 \\
\hline Palestine & 92.5 & 3.4 & 3.7 & 0.4 \\
\hline West Bank & 91.3 & 3.7 & 4.4 & 0.6 \\
\hline $\begin{array}{l}\text { North of West } \\
\text { Bank }\end{array}$ & 95.5 & 3.5 & 1.0 & 0.0 \\
\hline $\begin{array}{l}\text { Middle of West } \\
\text { Bank }\end{array}$ & 96.6 & 2.3 & 1.1 & 0.0 \\
\hline $\begin{array}{l}\text { South of West } \\
\text { Bank }\end{array}$ & 81.4 & 5.2 & 11.8 & 1.6 \\
\hline
\end{tabular}

percentage of healthcare facilities connected to water networks are almost the same in the years 2012 and 2014 , reliance of alternatives sources of freshwater becomes heavier almost in all regions at every level.

As shown in Table 1, it was found that $92.1 \%$ of the healthcare facilities in 2014 in the West Bank were provided with freshwater from public water networks, $12.9 \%$ of them purchased water tanks, $10.8 \%$ of them depended on harvested rainwater, and $1.0 \%$ of them used other sources of freshwater such as springs. It is interesting to know that these figures were almost the same at the country level, i.e., West Bank and Gaza Strip. Both water tanks and rainwater harvesting systems represent appropriate alternatives for local residents who live in vulnerable communities where public water network does not exist or of intermittent supply. These two sources, i.e., tankers and cisterns, are used to complement water supplied by public water networks (ARIJ 2015). Such trend is obvious when the middle of the West Bank region of the highest percentage of healthcare facilities connected to networks in both years is compared to the southern West Bank region of the highest percentages of tankers and cisterns used. 
Rainwater harvesting systems could reveal some microbiological and physiochemical contaminants, waterborne diseases may arise (Sánchez et al. 2015). Daoud et al. (2011) assessed the quality of rainwater harvesting systems in different areas in the West Bank and found that all 42 samples taken in the summer and winter contained coliforms and $67 \%$ of them were contaminated with fecal coliforms. The physiochemical quality of the harvesting systems was generally acceptable, while most samples were biologically contaminated with pathogenic microorganisms which posed health risks.

Al-Batsh et al. (2019) made an assessment of the chemical, physical, and biological quality of water in 100 rainwater harvesting systems at Hebron district. Water samples were analyzed for various parameters including $\mathrm{pH}$, chloride, alkalinity, $\mathrm{NH}_{4}, \mathrm{NO}_{3}$, salinity, total dissolved solids, turbidity, hardness, temperature, total coliforms, and fecal coliforms. Al-Batsh et al. (2019) found that harvested water has good physicochemical quality; yet, the majority of the samples have high amounts of total and fecal coliforms.

Continuous maintenance and disinfection of rainwater harvesting system are necessary to provide water source of acceptable quality, particularly for healthcare facilities. In order to prevent health risks posed by pathogens in harvested rainwater, safety measures have to be practiced during the construction and the operation of the system. Such measures include building cement or rock walls to avoid wastewater intrusion, cleaning the roof catchment systems and cistern top area from animal droppings and pesticide deposits, installing first flush diverter to the system, routing runoff in a closed roof drain system, disinfecting harvested rainwater, and testing water quality (see Daoud et al. 2011; Al-Batsh et al. 2019). Keep in mind, rainwater harvesting systems have low operating and maintenance costs (Al-Batsh et al. 2019).

Using water tanks reveals a biological contamination that might result in microbial water quality, especially in stainless steel tanks. Fecal streptococcus, fecal coliforms, and total coliforms are all called indicator bacteria that indicate microbial contamination or pollution. Chemicals such as chloride, nitrate, and sodium may accumulate in tanks in concentrations that may exceed both the Palestinian and WHO standards (Aish 2013). MoH (2017) tested 1520 samples from water tanks in the West Bank schools of which 299 were contaminated.

It is known that stagnation of water in tanks when stored for prolonged periods might result in the growth and transmission of pathogenic bacteria. Furthermore, water tanks have to be periodically cleaned and disinfected to kill pathogens and keep water safe to drink. In fact, water tanks might not meet minimum health requirement and further caution has to be exercised when dealing with tank water which is usually of unknown origin and age. Furthermore, the cost of water from tankers may approach four times the regular selling price of clean water (ARIJ 2015; Al-Batsh et al. 2019). In effect, tanks become an infeasible water source of doubtful quality for domestic uses (Amnesty International 2009), specifically in healthcare facilities.

In effect, water tanks and rainwater harvesting systems have revealed some microbiological and physiochemical contamination (see Aish 2013; Sánchez et al. 2015; MoH 2017; Alazzeh et al. 2019; Al-Batsh et al. 2019). Public water networks represent a safer alternative to supply water services for healthcare facilities in Palestine. However, public water networks are generally outdated (UNDP 2014; Al-Batsh et al. 2019) and this may result in possible contamination of water supplies. There is a higher potential of contamination to water networks since $45 \%$ service providers of the in the West Bank declared their sewer networks are of poor or partially poor performance, $30 \%$ of them admitted that their networks have serious leakage problems, and 59\% of them stated that their sewer networks experience frequent flooding (WSRC 2019).

Typically, water comes from the network to a storage water tank (or holding tank) on the rooftop of the healthcare facility to use during the outage of local water service which frequently occurs in the summer months. About $92 \%$ of the households in the West Bank have storage water tanks (World Bank 2018) and 51\% of them only have a daily network water supply (ARIJ 2015). Water quality in rooftop tanks may be influenced by many factors such as temperature, storage duration, tank material and covering, site-specific conditions, and supply intermittency. Thereby, water storage rooftop tanks in the healthcare facility have to be maintained clean and safe to use. Almost $82 \%$ of hospitals in Bhutan have water storage tanks, while $78 \%$ of healthcare facilities in Cambodia have water storage tanks (WHO and UNICEF 2019).

The question now is whether the Palestinian public water networks provide freshwater of acceptable quality for domestic uses or not. In 2016, MoH (2013) took 9908 water samples from the public health central laboratory in Ramallah and found that $13.2 \%$ of the 
samples did not pass the tests made in 2012. The same tests were conducted in 2016 and $14.7 \%$ of the 12,186 water samples from the central laboratory did not pass these tests (MoH 2017). In 2016, MoH (2017) tested 71 samples from water networks in the West Bank and found that 7 samples were contaminated. Nanotechnology, e.g., nano membrane, can serve as a good solution for water filtration and purification (Khan et al. 2012) and remove physical, chemical, and biological contamination (Madhura et al. 2018). Researchers are nowadays working on water treatment processes with nanotechnology including membrane filtration, decontamination of microbes, catalytic degradation, and removal of micropollutants (Madhura et al. 2018).

Alazzeh et al. 2019 examined how intermittent water supply affects the water quality in two communities in Bethlehem districts and tested 718 water samples for residual chlorine, Escherichia coli (E. coli), and total coliforms. It was found that systems with intermittent water supply can deteriorate water quality and result in chemical and biological contamination (see Alazzeh et al. 2019; WHO and UNICEF 2019). Regardless of the primary source of freshwater, the water quality has to be regularly examined and compared to respective local guidelines and international standards (see WHO 2015; WHO and UNICEF 2019).

It is important to mention here that water are wastewater services in Palestine are mainly controlled by Israel, and inadequate infrastructure is the major limiting factor for any development to these services (UNDP 2014; UNESCWA 2020). The estimated volume of water consumed by the healthcare facilities in the West Bank in 2014 was 59.6 thousand cubic meters per month (see Fig. 3). Figure 3 also depicts the predicted amounts of generated wastewater by healthcare facilities according to the percentages determined by the PCBS (2002) and the World Bank (2018) studies. Generated wastewater commonly represents $80 \%$ of consumed water in Palestine (PCBS 2002; World Bank 2018) as shown in Fig. 3.

Almasi et al. (2006), however, had determined several correlations between socio-economic and climatic conditions on one side, and water consumption and wastewater generation rate on the other side. Details on socio-economic characteristics of the health sector in Palestine can be explored in several previous studies (e.g., Pfeiffer 2001; MoH 2013, 2017, 2019; World Bank 2016; SHOPS Plus 2018).

As for the consumed water in healthcare facilities, the maximum value of the average quantity is in the middle districts, especially Ramallah and Al-Bireh, where large healthcare facilities and clinics in the West Bank exist. However, average quantity of consumed water in the northern districts is lower than that of the southern district that is highly populated and larger number of visitors is expected. While Gaza Strip is almost the highest populated area in the world, water consumed in healthcare facilities is less than half that of the West Bank (see Fig. 3). This is because of the growing shortage of water supplies available for domestic uses coupled with the water quality crisis in Gaza Strip (see PWA 2014; ARIJ 2015; World Bank 2018).

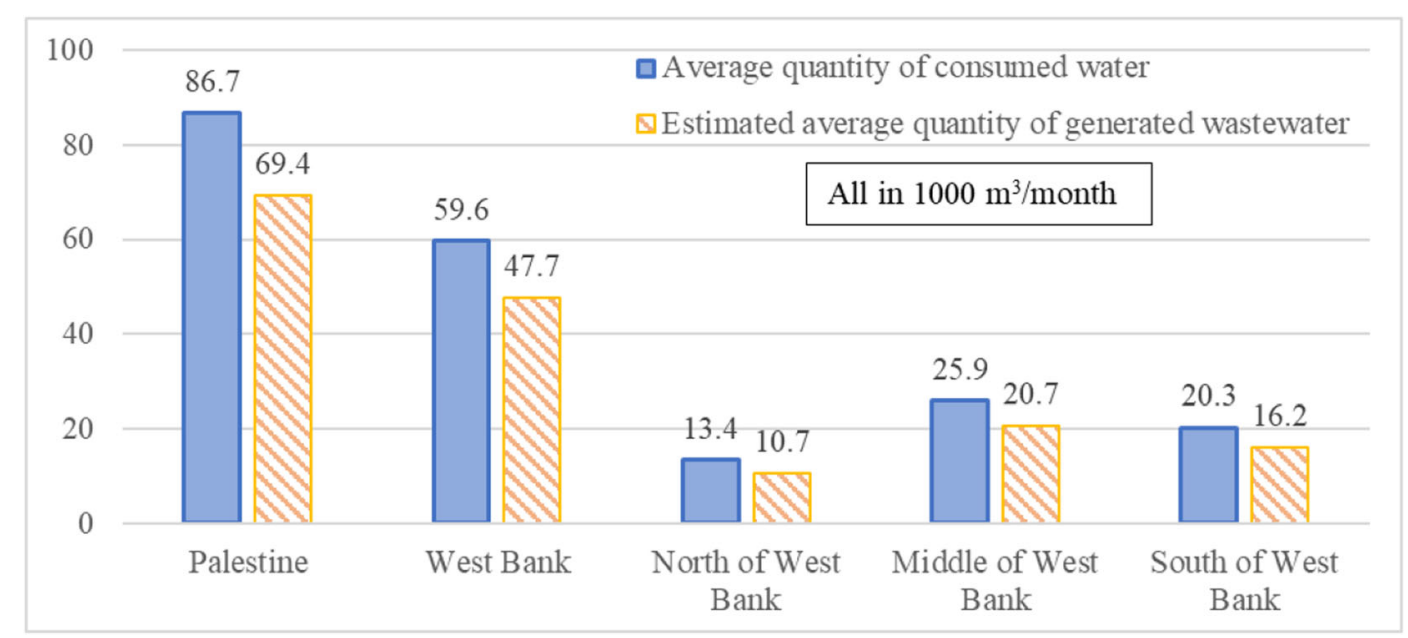

Fig. 3 Estimated monthly average quantity of consumed water and generated wastewater for healthcare facilities in Palestine by region (see PCBS and $\mathrm{MoH} 2014)$ 
Water supplies in healthcare facilities may not necessarily meet the national water quality standards, and sometimes water becomes contaminated in the facilities' distribution networks (WHO and UNICEF 2019). In the West Bank, the MoH regularly tests water samples taken from water sources, networks, tanks, rainwater harvesting cisterns, etc. Almost 8782, 11,980, and 12,394 water samples were tested in 2012, 2016, and 2018, and the contamination percentages were 12.9, 14.7, and 13.3\%, respectively ( $\mathrm{MoH} 2013,2017$, 2019), attracting more attention to the quality of water supplies, particularly in healthcare facilities. These contamination percentages are quite high for the quality of freshwater sources. Except the PCBS (2002) study, there is no single test to any wastewater sample in the studies of the MoH, i.e., $\mathrm{MoH}(2013,2017,2019)$.

The $\mathrm{MoH}$ is therefore invited to examine the quality of water and wastewater supplies in the healthcare facilities of the West Bank. The Palestinian Water Authority (PWA) is responsible for securing reliable water and sanitation services (ARIJ 2015) according to the water law number 2 of 1996 which was amended to the law number 3 of 2002 (PWA 2013a) and finally to the law number 14 of 2014 (PWA 2018; WSRC 2019). The local authorities such as joint service councils, municipalities, and village councils provide homes and facilities including healthcare facilities with water and wastewater services (ARIJ 2015). Among the 54 West Bank service providers by the end of $2017,70 \%$ of them provide both water and wastewater services and $85 \%$ of them are either a municipality or a village council (WSRC 2019). Each stakeholder has his own rights and responsibilities in the water and wastewater sectors.

The World Health Organization (WHO 2015) assessed the water, sanitation, and hygiene (WASH) services provided by 66,101 healthcare facilities in 54 lower-income countries. Indicators to sustain the WASH services in healthcare facilities and achieve relevant sustainable development goals of the United $\mathrm{Na}-$ tions were recommended by the WHO and UNICEF (2018), UNESCWA (2020), and others. A clear national plan and standards to provide acceptable levels of WASH services in healthcare facilities have to be set and applied immediately. A survey study in 2013 showed that 94 developing countries do not even have national policies or plans on WASH services in healthcare facilities (WHO 2015).

Again, most water used becomes wastewater within the distance from faucet to sink. Typically, generated wastewater represents a considerable portion of consumed water. For successful planning and management of the sanitation system, it is significant to determine the generated quantity and associated quality of wastewater in the West Bank. The volume of the collected wastewater in the West Bank was 29.01 million cubic meters in 2017 (WSRC 2019). Therefore, exact quantification of generated wastewater is helpful when building associated infrastructure and designing required facilities that serve collection, transportation, treatment, and disposal processes (see Almasi et al. 2006; Paleologos et al. 2020). In the West Bank, $43 \%$ of wastewater service providers send collected wastewater to a wastewater treatment plant (WWTP), $26 \%$ of them discharge wastewater into nearby valleys, and $31 \%$ of them connect wastewater to an Israeli network (WSRC 2019).

The characteristics of wastewater vary depending on many factors including the source and associated activities as well as the physical and climatic conditions, and therefore, have to be precisely classified and described (see Nashashibi 1995; Nashashibi and van Duiji 1995; PCBS 2002; Khan et al. 2012, 2019, 2020; Madhura et al. 2018). As an example, higher wastewater concentrations are attributed to lower water consumptions (Almasi et al. 2006) and this agrees with what Nashashibi and van Duiji (1995) observed in Palestine. Accordingly, the characteristics of wastewater will definitely influence the type of treatment effluents require (see Khan et al. 2012, 2019, 2020; Madhura et al. 2018; WSRC 2019). The wastewater disposal technique, in addition, will definitely impact human health and the environment. The proper understanding the wastewater collection, transport, treatment, and disposal processes in the healthcare facilities is essential to better manage this sector. Opportunities such as wastewater reuse are scarce if these processes are not appropriately applied.

\section{Wastewater}

\section{Wastewater disposal techniques}

Due to the inadequate infrastructure of wastewater, it is estimated that 25 million cubic meters of untreated effluents is annually discharge into the environment at more than 350 localities in the West Bank (UNPD 2014). The existing guidelines of WHO state that wastewater of healthcare facilities can be directly discharged into the domestic wastewater network just in case local regulations are met (Khan et al. 2020). If not, onsite 
treatment schemes are suggested in particular in rural healthcare facilities followed by sludge disposal techniques (Khan et al. 2020). According to the WHO regulations, drugs and hazardous chemical wastes must not be drained directly into the wastewater network, yet such substances must be assembled apart and go through treatment processes before being discharged into the wastewater network (WHO 2017b).

Unfortunately, this does not happen in the West Bank (see Table 2), and thus treatment is not applied in the vast majority of the healthcare facilities (PCBS 2002, 2012; PCBS and MoH 2014). Comparing the results of 2014 (PCBS and MoH 2014) to those of 2012 (PCBS 2012), the figures are almost similar with one exception on the percentage of healthcare facilities that have wastewater treatment which became half of that of the year 2012. The reason of such difference is the percentage of healthcare facilities that have wastewater treatment in the north of the West Bank region which was $7.9 \%$ in 2012 (PCBS 2012) and dropped significantly to $2.6 \%$ in 2014 (PCBS and MoH 2014). In addition, there were no data coming from the southern West Bank region in 2014 (PCBS and MoH 2014) regarding the percentage of healthcare facilities that have wastewater treatment while it was $4.8 \%$ in the year 2012 (PCBS 2012).

Table 2 shows that $93.0 \%$ of the Palestinian healthcare facilities are connected to public water networks in 2014, while only $45.3 \%$ of them are connected to wastewater networks. These percentages are larger than those in other developing countries such as Cambodia and Ethiopia (WHO 2017a). In Nepal, for

Table 2 Selected environmental indicators about healthcare facilities in Palestine

\begin{tabular}{|c|c|c|}
\hline Environmental indicator & $2014^{*}$ & $2012^{* *}$ \\
\hline $\begin{array}{l}\text { Percentage of the healthcare facilities connected } \\
\text { to public water networks }(\%)\end{array}$ & 93.0 & 92.5 \\
\hline $\begin{array}{l}\text { Percentage of the healthcare facilities connected } \\
\text { to wastewater networks }(\%)\end{array}$ & 45.3 & 42.1 \\
\hline $\begin{array}{l}\text { Percentage of the healthcare facilities which have } \\
\text { wastewater treatment }(\%)\end{array}$ & 2.2 & 5.0 \\
\hline $\begin{array}{l}\text { Monthly amount of consumed water by } \\
\text { healthcare facilities }\left(\times 1000 \mathrm{~m}^{3}\right)\end{array}$ & 86.7 & 85.0 \\
\hline $\begin{array}{l}\text { Monthly amount of generated wastewater by } \\
\text { healthcare facilities }(80 \% \text { of consumed water) } \\
\left(\times 1000 \mathrm{~m}^{3}\right)\end{array}$ & 69.4 & 68.0 \\
\hline
\end{tabular}

instance, about $62 \%$ of healthcare facilities have access to piped water and $78 \%$ of them have sewer connections or septic tanks (WHO and UNICEF 2019). Compared to 66,101 healthcare facilities in 54 developing countries, $62 \%$ of them provide users access to improved water sources (WHO 2015). However, $81 \%$ of 62,524 healthcare facilities in 36 developing countries provide users access to improved sanitation facilities (WHO 2015). Unfortunately, the WHO (2015) study did not cover Middle Eastern countries well and therefore, comparison with neighboring countries was not possible. Compared to 65 developing countries in the whole world, WHO and UNICEF (2019) showed that all healthcare facilities in Palestine have improved sanitation services.

These environmental indicators have to be carefully studied and lessons should be learned for better planning and management of the water resources in Palestine. Wastewater networks are typically connected to the stormwater drainage system which can be harvested, and hence, separation is necessary for a good governance of existing resources (Amnesty International 2009; PWA 2013a). Stormwater drainage system can be harvested for non-potable water purpose of lower water quality. Harvested stormwater can be utilized in small-scale purposes such as to water gardens, flush toilets, wash grounds, and cool air-conditioning systems, as well as in large-scale projects such as to irrigate plants, recharge groundwater resources, etc. Only a few stormwater harvesting systems exist in the West Bank (PWA 2013a).

Although separation of wastewater networks from stormwater drainage system is to be considered in any future policy and strategy in Palestine, yet this is not good enough to protecting the public health and the environment (Amnesty International 2009). The characteristics and constituents of wastewater of healthcare facilities are different than those of municipal wastewater (WHO 2017b). In effect, medical wastewater should be disposed in a separate system such as an on-site treatment unit so that effluents could be treated and safely discharged into the environment (see WHO and UNICEF 2019; Bhowmick et al. 2020). On-site wastewater treatment unit often includes primary, secondary, and tertiary treatment processes (Khan et al. 2019, 2020). This option, however, could be neither feasible nor practical for small-scale healthcare facilities like those in the West Bank. Instead, wastewater has to be adequately treated or disinfected before being 
discharged into a municipal wastewater network (see Hocquet et al. 2016).

Several types of antibiotics may be found in the wastewater of healthcare facilities, including tetracyclines, fluoroquinolones, macrolides, quinolones, glycopeptides, and sulfonamides (see Khan et al. 2020). Antibiotics cause growing bacterial resistance and these compounds may be discharged with WWTP effluents to the surface water as these effluents are hard to separate using conventional WWTPs (Boy-Roura et al. 2018). This antimicrobial resistance of untreated wastewater at healthcare facilities is considered one of the strongest threats to human health in the world (WHO and UNICEF 2019). The bacterial resistance against antibiotics of the medical wastewater can be as high as 2 to 10 times higher as that in domestic wastewater (WHO 2017b).

Although $45.3 \%$ of the healthcare facilities in the West Bank got rid of the wastewater via wastewater networks in 2014, yet $28.6 \%$ of them utilized porous cesspits and $26.1 \%$ of them used tight cesspits as shown in Table 3. Wastewater networks are only available in major cities and refugee camps, and there is a dire need to appropriate infrastructure for collection and treatment

Table 3 Percentage distribution of healthcare facilities in Palestine by wastewater disposal method and region in the year a. 2014 and b. 2012

\begin{tabular}{|c|c|c|c|c|c|}
\hline \multirow[t]{2}{*}{ Region } & \multicolumn{5}{|c|}{ Wastewater disposal method (\%) } \\
\hline & $\begin{array}{l}\text { Wastewater } \\
\text { network }\end{array}$ & $\begin{array}{l}\text { Tight } \\
\text { cesspit }\end{array}$ & $\begin{array}{l}\text { Porous } \\
\text { cesspit }\end{array}$ & Total & \\
\hline \multicolumn{6}{|c|}{ a. Year 2014 (PCBS and MoH 2014) } \\
\hline Palestine & 45.3 & 26.1 & 28.6 & 100 & \\
\hline West Bank & 36.6 & 29.6 & 33.8 & 100 & \\
\hline $\begin{array}{l}\text { North of West } \\
\text { Bank }\end{array}$ & 27.4 & 41.1 & 31.5 & 100 & \\
\hline $\begin{array}{l}\text { Middle of } \\
\text { West Bank }\end{array}$ & 44.0 & 18.3 & 37.7 & 100 & \\
\hline $\begin{array}{l}\text { South of West } \\
\text { Bank } \\
\text { b. Year } 2012(P\end{array}$ & $\begin{array}{l}42.6 \\
\text { CBS 2012) }\end{array}$ & 23.6 & 33.8 & 100 & \\
\hline Palestine & 42.1 & 24.7 & 32.9 & 0.3 & 100 \\
\hline West Bank & 34.9 & 28.9 & 35.8 & 0.4 & 100 \\
\hline $\begin{array}{l}\text { North of West } \\
\text { Bank }\end{array}$ & 27.5 & 37.0 & 35.5 & 0.0 & 100 \\
\hline $\begin{array}{l}\text { Middle of } \\
\text { West Bank }\end{array}$ & 49.0 & 15.1 & 34.9 & 1.0 & 100 \\
\hline $\begin{array}{l}\text { South of West } \\
\text { Bank }\end{array}$ & 35.9 & 26.8 & 36.7 & 0.6 & 100 \\
\hline
\end{tabular}

(ARIJ 2015; WSRC 2019). Keep in mind that only $55.5 \%$ of Palestinian households are connected to wastewater networks (UNDP 2014). Therefore, a number of municipalities and village councils are working on constructing the infrastructure needed to provide wastewater services (PWA 2018; World Bank 2018; WSRC 2019). Even though, healthcare wastewater still includes hazardous substances that require proper handling and treatment before being discharged into the wastewater network.

The high percentage of using tight cesspits as a wastewater disposal method in the healthcare facilities of the north of the West Bank is attributed to the low percentage of facilities connected to wastewater networks. Despite the larger cities, rural areas with dispersed housing patterns dominate and a few wastewater networks exist in the north of the West Bank. An opposite trend is noticed in the middle of the West Bank in which most healthcare facilities lie in Ramallah and AlBireh district, the leading center of economic and political activities in the Palestinian territory. A civilized and urban zone such as Ramallah and Al-Bireh district is expected to have a good coverage of wastewater network. The sewerage coverage ratios in the municipalities of Ramallah and Al-Bireh cities, for instance, are 80 and $93 \%$, respectively, among the highest $35 \%$ of service providers in coverage ratio (WSRC 2019).

Tight cesspits or septic tanks, however, are usually built with non-porous materials such as bricks, concrete, metal, or plastic. Once tight cesspits are filled off, vacuum tankers dispose the wastewater (raw sewage) into surrounding farms and nearby wadis (see UNDP 2014; ARIJ 2015; World Bank 2018) resulting in the spread of infectious diseases and environmental pollution (EEA 2014; WHO and UNICEF 2019). The soil will be polluted with pathogenic organisms and microorganisms such as $E$. coli which will definitely cause risks to human health and the environment, as well (WHO 2015; Siggins et al. 2016). Almost $76 \%$ of the vacuum tankers discharge wastewater into nearby valleys, $17 \%$ of them dispose it into WWTPs, and 7\% of them transport it to Israeli networks (WSRC 2019).

As for porous cesspits, they are basically underground chambers of permeable walls that infiltrate wastewater into surrounding areas. In the West Bank, porous cesspits are on purpose constructed of porous materials to allow seepage into underlying soil (ARIJ 2015). The percolating leachate contaminates the surrounding soil layers and pollutes the groundwater aquifers, as well (Khan et al. 
2019). In some cases, local residents suffer from contamination of water harvesting system by wastewater in the same household. Therefore, wastewater from porous cesspits will pollute existing land and water resources, and so will wastewater from tight cesspits when not properly installed (see Bhowmick et al. 2020).

It is worth to mention that the majority of Palestinian households rely on cesspits for wastewater storage (UNDP 2014). Anayah and Almasri (2009) showed that leaking cesspits result in groundwater nitrate contamination, particularly in the northern West Bank districts. Werner et al. (2000) showed that the West Bank groundwater is mainly polluted by wastewater from leaking cesspits. The situation is likely to get worse when we deal with wastewater of healthcare facilities. Almost at all levels, from multi-district to countrywide, the porous cesspits are used as a wastewater disposal method in approximately one-third of the healthcare facilities (see Table 3). There is no significant difference in the figures in Table 3 between the years 2012 and 2014, except having some other disposal methods of the wastewater in 2012 which were not defined in the source itself, i.e., PCBS (2012).

According to the WHO recommendations with regard to wastewater origins from medical laboratories, pre-treatment of hazardous chemicals including acidbase neutralization, filtering to remove sediments, liquidation, or autoclaving infectious samples is advisable (WHO 2017b). To assess the quality of medical wastewater, several parameters including chlorine, $\mathrm{NH}_{4}$, suspended solids, chemical oxygen demand, biological oxygen demand, heavy metals, radioactive metals, antibiotic residues, and bacterial pathogens have to be determined (Khan et al. 2020). Non-hazardous chemicals such as eye drops, syrups, and vitamins require no pretreatment before discharging into the sewerage system (WHO 2017b).

\section{Wastewater treatment}

Wastewater treatment includes all processes that make wastewater quality comply with environmental standards and allow effluents to be safely discharged into the environment (PCBS 2002). The three types of wastewater treatment are mechanical, biological, and chemical processes. Typically, wastewater generated by healthcare facilities is generally treated through activated sludge processes, sequencing batch reactors, membrane biological reactors, activated carbon techniques, carbon nanotube techniques, and upflow anaerobic sludge blanket techniques (Khan et al. 2020). Physiochemical treatment techniques of medical wastewater include ultraviolet/hydrogen peroxide (UV/ $\mathrm{H}_{2} \mathrm{O}_{2}$ ), Fenton reagent, and Ozonation $\left(\mathrm{O}_{3}\right)$ (Khan et al. 2020). Nanotechnological systems are lately used for wastewater treatment including multiple separation processes, e.g., reverse osmosis, microfiltration, and nanofiltration, of which reverse osmosis is the best process in removing all micropollutants (Madhura et al. 2018).

As mentioned earlier, pre-treatment of healthcare facilities' wastewater (e.g., sedimentation, filtration, flocculation, acid-base neutralization, liquidation or autoclaving) is recommended by the WHO (2017b) before being discharged into the sewerage system (UN 1997). In some societies, wastewater of healthcare facilities is directly discharged to municipal drainage systems, and therefore fears from parasitic (or enteric) and epidemic diseases arise (see WHO and UNICEF 2019). In the streams of healthcare WWTP, chlorinated organic compounds and heavy metals such as mercury and lead are often detected (Windfeld and Brooks 2015).

Almost $>95 \%$ of toxic compounds are extracted and filtered by the WWTP (Ryan-Fogarty et al. 2016). Classical processes of wastewater treatment, such as activated sludge together with suspended growth, are successful in domestic wastewater treatment, yet they are not capable to completely remediate medical wastewater (Alimohammadi et al. 2018). In the States, only a few states motivate elementary remediation of healthcare effluents prior to drainage into domestic wastewater influent for remediation in municipal WWTP (Hocquet et al. 2016). The membrane biological reactors are considered the best for treatment of medical wastewater as they are effective in reducing levels of sludge and suspended solids as well as eliminating pathogens and some other micropollutants (Khan et al. 2020).

Out of the 54 wastewater service providers in the West Bank, only $37 \%$ of them provide wastewater treatment (WSRC 2019). Out of the 29.01 million cubic meter collected wastewater in the West bank in 2017, 9.99 million cubic meters of wastewater were treated (WSRC 2019). Among the 20 WWTPs exist in the West Bank, large municipal WWTPs serve the big-city municipalities of Hebron, Ramallah, Jericho, Tulkarm, Jenin (UNPD 2014), and more recently Nablus, Salfit, Al-Bireh, and Tubas (PWA 2018). Many of these WWTPs are working at 10-30\% efficiency (UNDP 
2014), and therefore, treated effluents do not comply with relevant standards (WSRC 2019). While the sewer network coverage in the West Bank was $29 \%$ in 2015, it increased to $34 \%$ in 2017 (WSRC 2019). According to strategy approved by the Palestinian government in 2013, $80 \%$ of the West Bank population should have safe and appropriate sanitation services as well as efficient and proper WWTPs, so that at least $70 \%$ of their treated effluents is reused in agriculture by the year of 2032 (PWA 2018). Surface drip irrigation is recommended to reduce pathogens as soil is considered a multilayer natural filter (Madhura et al. 2018).

As for the large Palestinian healthcare facilities or hospitals which are not connected to the treatment plant, it is advised to utilize their own equipment for wastewater treatment. This equipment should use chemical, physical, and biological processes to remove contaminants. Table 4 shows that only 5.0 and $2.2 \%$ of the healthcare facilities in Palestine retreated their wastewater in the years 2012 and 2014, respectively, and these are small percentages. It is interesting to compare the figures of the two studies (i.e., PCBS 2012; PCBS and $\mathrm{MoH} 2014$ ) and see if there is any pronounced trend.

Table 4 Percentage distribution of healthcare facilities in Palestine by existence of wastewater treatment, method of treatment, and region in the a. year 2014 and b. year 2012

\begin{tabular}{|c|c|c|c|c|}
\hline \multirow[t]{2}{*}{ Region } & \multicolumn{3}{|c|}{$\begin{array}{l}\text { Method of wastewater } \\
\text { treatment }(\%)\end{array}$} & \multirow{2}{*}{$\begin{array}{l}\text { Existence of } \\
\text { wastewater } \\
\text { treatment }(\%)\end{array}$} \\
\hline & $\begin{array}{l}\text { Mechanical } \\
\text { treatment }\end{array}$ & $\begin{array}{l}\text { Chemical } \\
\text { treatment }\end{array}$ & Total & \\
\hline
\end{tabular}

a. Year 2014 (PCBS and MoH 2014)

\begin{tabular}{|c|c|c|c|c|}
\hline Palestine & 57.9 & 42.1 & 100 & 2.2 \\
\hline West Bank & 66.9 & 33.1 & 100 & 2.0 \\
\hline $\begin{array}{l}\text { North of } \\
\text { West Bank }\end{array}$ & 100.0 & 0.0 & 100 & 2.6 \\
\hline $\begin{array}{l}\text { Middle of } \\
\text { West Bank }\end{array}$ & 25.0 & 75.0 & 100 & 3.5 \\
\hline $\begin{array}{l}\text { South of } \\
\text { West Bank } \\
\text { b. Year } 2012(P\end{array}$ & PCBS 2012) & - & - & - \\
\hline Palestine & 62.1 & 37.9 & 100 & 5.0 \\
\hline West Bank & 60.4 & 39.6 & 100 & 5.7 \\
\hline $\begin{array}{l}\text { North of } \\
\text { West Bank }\end{array}$ & 59.6 & 40.4 & 100 & 7.9 \\
\hline $\begin{array}{l}\text { Middle of } \\
\text { West Bank }\end{array}$ & 0.0 & 100.0 & 100 & 2.3 \\
\hline $\begin{array}{l}\text { South of } \\
\text { West Bank }\end{array}$ & 82.4 & 17.6 & 100 & 4.8 \\
\hline
\end{tabular}

The percentages of existing wastewater treatment in 2012 were mostly doubled, if not tripled in some cases (see Table 4). Policy and decision makers have to study these figures and understand how they have changed in a period of only 2 years. Overall, the percentages of the wastewater treatment methods are quite similar for the years 2012 and 2014 at the West Bank and county-wide levels although no data were collected from the southern districts. The discrepancies between practices, i.e., mechanical and chemical treatment processes, applied in the north as well as the middle of the West Bank are significant in both years.

As for the mechanical or physical treatment, it includes processes such as sedimentation and flotation (PCBS 2012; PCBS and MoH 2014), and usually consists of fine grids or screens that help remove floating or dispersed solid matter from wastewater, e.g., plastic bags, rags, or other substances. Mechanical treatment also removes raw materials that might clog pipelines and pumps of the treatment plant, and therefore, it comes first. The mechanical treatment is combined with biological and some advanced processes (PCBS 2002, 2012; PCBS and MoH 2014), and this combination successfully removes micropollutants and as a result is adopted widely in Europe (Khan et al. 2020). However, chemical treatment includes acid-base neutralization and reduction of water solubility to breakdown hazardous wastes and remediates the chemical properties of the wastes (PCBS 2002; PCBS and MoH 2014). Each single treatment process has its own pros and cons as shown in the literature, and therefore, blended processes and hybrid models are designed and applied by the different systems at different scales given the economic feasibility of the methods (see Khan et al. 2020).

The treatment results mainly in reducing the filtration of hazardous compounds into the environment. Whenever these chemicals reach the water bodies, i.e., surface water and groundwater, they will be highly harmful to humans, animals, and plants. There are more than a strategy to improve wastewater management, such as decreasing wastewater production and applying on-site sewage facility (see Nashashibi 1995; PWA 2013a; ARIJ 2015; Madhura et al. 2018; Khan et al. 2019, 2020). Water conservation, e.g., lowering the flow of showers and toilet flushes, will decrease the generation of wastewater. In the West Bank, the overflows of sewage are more frequent in the northern districts, specifically Salfit and Tubas (World Bank 2018). On-site handling of wastewater stream will let reuse and 
recycling of reclaimed water available as well as elimination of pharmaceuticals and pathogens (WHO 2015; Khan et al. 2019, 2020).

Untreated wastewater will cause many impacts to human health and the environment, because of the appearance of many harmful contaminants. E. coli and heterotrophic bacteria resistant to tetracycline, sulfamethoxazole, and amoxicillin are examples of the existing bacteria in wastewater (Proia et al. 2018), causing many diseases to humans when exposed to them. Anticancer drugs are also released from hospital wastewater; they are toxic to humans after they reacted with some elements and chemicals in the wastewater (Isidori et al. 2016).

A broad zone of human medicines is also released into the wastewater effluent including antibiotics, stains, or cytotoxins used in cancer treatment and pharmaceuticals (Sim et al. 2013). Medicines may also be disposed into the wastewater causing exposure to anthelmintics such as albendazole and flubendazole which are used for parasitic infection and veterinary medicine (Sim et al. 2013). Antibacterial and antifungal agents may participate to the stress on the environment, essentially as they directly reach the soil and the surface water. Such agents may have ecological impacts such as endocrine disruption to biota within the environment (Baker et al. 2014).

Disinfectants, pharmaceuticals, and radionuclides are excessively consumed in healthcare facilities for medicinal aims (Madhura et al. 2018; Khan et al. 2019, 2020). These substances will combine with the effluent and finally reach the municipal sewer network. All of these substances will end up in the surface water, which will affect the ecosystem and eventually reach the food chain (Khan et al. 2020). High quantities of enteric viruses are released from hospital wastewater into the environment, and cause human gastroenteritis and other types of waterborne diseases even at very low doses (Galus et al. 2013). Therefore, service providers have to make sure that amounts of free residual chlorine in the freshwater are sufficient at the consumers' taps to eradicate such viruses including the COVID-19 (Bhowmick et al. 2020).

Unlike domestic wastewater, healthcare wastewater might include dangerous substances that require proper handling and treatment. Strategies to treat and reuse wastewater and effective solutions to dispose it safely in Palestine were profoundly addressed by Nashashibi (1995), PWA (2013a), ARIJ (2015), and World Bank (2018). The use of treated wastewater as a non- conventional water source for irrigation, as an example, is still a priority (UNDP 2014; WSRC 2019) as confirmed by the Palestinian water policy recently adopted by the government (PWA 2018).

Nanotechnology, however, provides a strong option for wastewater treatment using efficient nano-filters, for instance, the industry that emerged in Germany since 2006 and then grew rapidly around the world (Khan et al. 2012) Nevertheless, nanotechnology-related wastewater reuse is only applied at laboratory scale, and researchers have to address the challenges to design cost effective, industrial scale applications (Madhura et al. 2018). Further researches on nanotechnology methods and applications in pollution reduction, water disinfection, and wastewater treatment have been recently conducted (see Madhura et al. 2018; Khan et al. 2019, 2020).

Treated wastewater is satisfactorily reused for irrigation in seven out of the eight service providers that have active reuse programs in the West Bank (WSRC 2019). The reuse of treated domestic wastewater can be successful in agriculture because it provides a stable water source of high nutritious value, leading to larger food production (Madhura et al. 2018). Yet, reusing wastewater from healthcare facilities, exclusively in agriculture, is not recommended by WHO and UNICEF (2019) as such wastewater has high levels of chemical and biological contaminants in addition to its antimicrobial resistance (Khan et al. 2020). Given the present coronavirus pandemic, extra caution is required when treated wastewater is to be safely reused, and migration of the virus at the different stages in WWTP is to be carefully monitored (Bhowmick et al. 2020; Paleologos et al. 2020). The conventional WWTP with disinfection (e.g., chlorination, UV irradiation) is supposed to eradicate COVID-19 (Paleologos et al. 2020), but this has to be practically examined in developing countries (Bhowmick et al. 2020) such as Palestine.

All competent authorities are urged to setting up efficient management and maintenance programs for water and wastewater sectors in healthcare facilities and enforcing respective policies and laws (see PWA 2013a; World Bank 2018). In order to implement these policies and laws, sufficient political, human, and financial resources have to be allocated (WHO 2015). Private sector engagement in the development of these sectors is essential and its partnership with governmental agencies should always be welcomed in such a developing country as Palestine (see SHOPS Plus 2018). The 
involvement of the different stakeholders enhances accountability and transparency for a better management and development of the water and wastewater sectors.

Management of water and wastewater sectors

in the novel coronavirus pandemic

Regarding the WASH services in the Palestinian healthcare facilities, the focus of local competent authorities is on the personal and public hygiene, yet less attention is paid to the water and sanitation services during the novel coronavirus pandemic (see Bhowmick et al. 2020; Paleologos et al. 2020). In effect, the surveillance and monitoring of water supplies and wastewater services become more important to identify necessary interventions. More stringent measures and heightened procedures have to be applied to curb the spread of the COVID-19 disease.

Water sources shall be regularly inspected to make sure that water supplies are clean and safe to use. The risk of COVID-19 to water supplies is low as the virus has not been found in freshwater facilities in which precautions are taken under consideration (Bhowmick et al. 2020). COVID-19 exists in the solid and liquid wastes from infected patients can pollute soil and water resources (Paleologos et al. 2020). The fate and transport of contaminants and pathogens including the COVID-19 virus with the soil, surface water, and groundwater must be further studied (Madhura et al. 2018; Khan et al. 2019, 2020; Paleologos et al. 2020).

Scientists have recently proven that the novel coronavirus has been detected in the wastewater as many other diseases. As a result, water and wastewater services need to be frequently examined to reduce the possible spread of the COVID-19. As mentioned in the previous sections of this paper, water supplies are susceptible to contamination from the source itself or during transportation and storage. Water supplies may carry and transmit pathogens including the novel coronavirus (see Paleologos et al. 2020). Freshwater comes to healthcare facilities through public networks, tankers, and rainwater harvesting systems. Water networks are outdated and suffer from high rates of water losses. While tankers provide water of unknown sources and questionable qualities, rainwater harvesting systems require continuous maintenance and inspection.

In many rural areas, a rainwater harvesting cistern is a few meters away from the sewage cistern, and therefore, such water supplies are prone to contamination or even pollution in some cases. Freshwater contaminated with feces might increase the risk of COVID-19 transmission by several folds (Bhowmick et al. 2020). The migration of COVID-19 in soil and water is evident, yet, other investigations are still needed to explore possible pathways and survival times (Paleologos et al. 2020). It is high likely that COVID-19 virus can survive much longer in water and wastewater when suspended solids are of high values (Paleologos et al. 2020), particularly in low temperature regions (Bhowmick et al. 2020). Investigations (e.g., Bhowmick et al. 2020; Paleologos et al. 2020) show that temperature and incubation time are the significant factors to control the spread of COVID-19 in water networks.

Furthermore, the performance of wastewater networks is poor as they experience serious leakage problems and frequent flooding throughout the year. This simply means that it is high likely that freshwater can be mixed with wastewater in a way or another. No matter what the source of freshwater, the water quality has to be regularly examined and compared to local guidelines and international standards. Therefore, the authors believe that water and wastewater services should be managed differently after the onset of the COVID-19 virus in Palestine.

Several personal interviews with experts in the field had been conducted to better understand the situation of the WASH services after the coronavirus pandemic. The list of the Palestinian experts includes medical administrators from several healthcare facilities as well as administrative directors/officers in major governmental regulatory authorities and multiple service providers in the West Bank districts. The competent authorities in full cooperation with the providers of water and wastewater services in the West Bank prepared a contiguous plan to tackling the COVID-19 pandemic. The plan aims at increasing work readiness and communication channels among all stakeholders to reduce risks related to water and wastewater services. In effect, surveillance of water sources, monitoring of freshwater quality, measures of disinfection as well as the work of WWTPs are all intensified and become stricter.

Water and sanitation facilities should take every possible precautionary procedure and adhere to public health and safety instructions. Furthermore, hygiene practices in healthcare facilities require larger volumes of freshwater, produce increased quantities of wastewater, and make extra pressure on the water and sanitation infrastructure (see Paleologos et al. 2020; UNESCWA 
2020). As for the least developed countries, $22 \%$ of healthcare facilities have no water supply and $21 \%$ of them lack sanitation services, and therefore, additional infrastructure is needed after the COVID-19 pandemic (Paleologos et al. 2020). Developing countries including Palestine are urged to take actions in this direction.

The estimated increase in daily water consumption for hygienic purposes due to the COVID-19 pandemic is 9 to 12 1/capita in Palestine and other Arab countries (UNESCWA 2020). In order to support healthy hygiene behaviors, all water systems and features (e.g., faucets, fountains, sinks) are assured to be clean and safe to use in addition to the water supply. Water faucets and fountains in healthcare facilities may have germs from the skin of the user and could transmit diseases through the oral fluids, saliva, and sputum shed onto the faucets and fountains.

Azzi et al. (2020) and Wang et al. (2020) have proved the possible role of oral fluids in the detection of the COVID-19 virus. The COVID-19 disease can be transmitted through aerosol or when the saliva of a patient enters freshwater sources (Bhowmick et al. 2020). The high COVID-19 load on oral fluids and stool samples can contaminate wastewater generated from quarantine facilities and households of positive cases, and ultimately reach receiving water bodies (Bhowmick et al. 2020). In effect, the need for wastewater treatment in such cases becomes more urgent.

Recent investigations have focused on the possible means of respiratory and non-respiratory transmission of the COVID-19 virus (e.g., Paleologos et al. 2020; Wang et al. 2020). As for the non-respiratory transmission of the COVID-19 virus, bodily fluids taken from infected patients can play a significant role in healthcare facilities. Specimens of bodily fluids from confirmed cases of COVID-19 were examined and ordered by severity as follows: bronchoalveolar lavage, sputum, nasal swabs, fibrobronchoscope brush biopsy, pharyngeal swabs, feces, and lastly blood (Wang et al. 2020).

Furthermore, information collected from urine samples needs further verification because results are inconsistent. The viral ribonucleic acid (RNA) for COVID-19 was not detected in any of the 72 urine specimens from infected patients (Wang et al. 2020). However, urine samples tested positive for the novel coronavirus RNA in the Bhowmick et al. (2020), Farkas et al. (2020), and Xiao et al. (2020) studies. People need to take extra caution when it comes to healthcare facilities as elevated rates of human-to-human transmission of the COVID-
19 virus are expected. Insect vectors can transmit the COVID-19 virus to humans through their bodies or intestinal tracts in which the virus has better chances of survival and higher resistance (Bhowmick et al. 2020), especially in hot areas. In summary, the management of water and wastewater sectors under the COVID-19 pandemic conditions has to consider providing the services to the healthcare facilities qualitatively and quantitatively.

Wastewater becomes recently an efficient tool to indicate a possible viral outbreak and to halt the spread of a pandemic, e.g., the novel coronavirus, in a community (see Bar Or et al. 2020; Farkas et al. 2020). The severe acute respiratory syndrome virus RNA, which causes the COVID-19 disease, is shed in feces (Bar Or et al. 2020; Wang et al. 2020; Xiao et al. 2020) and detected in wastewater (Bhowmick et al. 2020; Farkas et al. 2020; Weidhaas et al. In review). Weidhaas et al. (In review) detected the COVID-19 virus in $61 \%$ of the 126 samples taken from 10 wastewater facilities in the state of Utah. Bar Or et al. (2020) detected the viral RNA for COVID-19 in raw sewage samples from several localities in Israel and developed an efficient tool for epidemiological surveillance of infection in large societies.

The RNA for COVID-19 virus has been found in hospital sewage network, wastewater collection systems, and ultimately in community waterways (Paleologos et al. 2020). The wastewater epidemiology supports public health responses to pathogens such as COVID-19, serves as an early warning of outbreaks in the community, and saves money, effort, and time in identifying disease emerging hotspots of elevated prevalence (Bar Or et al. 2020; Bhowmick et al. 2020; Weidhaas et al. In review). The wastewater epidemiology can simply collect chemical and biological information from a community and help decision makers confirm virus presence or validate containment systems (Bar Or et al. 2020).

In response to the attention paid by the global community regarding the novel coronavirus pandemic and how it affects recommended procedures and protocols to curb its spread, several experts in the West Bank had been also interviewed in this regard. The international recommendations of the WHO about healthy hygiene practices are followed wherever possible or necessary. The experts, however, were asked if there are any new directives, instructions, procedures, or safety measures revised after the onset of the novel coronavirus COVID19 about dealing with water supplies or wastewater 
management in general and more specifically in healthcare facilities. It does not matter if these new action protocols are within the institution of the interviewed expert via internal circulations, or at a national level from competent authorities such as the PWA or the $\mathrm{MoH}$.

Healthcare facilities include the MoH, Health Care Military Services, Lijan Az-Zakah, Health Union Committees, Union of Palestine Health Care Relief Committees, Patients Friends Benevolent Society, UNRWA, and Palestine Red Crescent Society in the districts of Nablus, Tulkarm, Qalqilya, and Ramallah and Al-Bireh. The regulatory authorities include the PWA, WSRC, $\mathrm{MoH}$, Environment Quality Authority, Ministry of Agriculture, and Union of Palestinian Water Service Providers in the Jenin, Qalqilya, and Ramallah and AlBireh districts. The service provides are the municipalities, joint service councils, and water supply and sewerage authorities in the 10 districts of the West Bank.

The Palestinian $\mathrm{MoH}$ has recently released an emergency media brochure on its Facebook page that includes directives to public and private institutions after the onset of the novel coronavirus pandemic, but the brochure has nothing specific about water and wastewater services. PWA (2020) gives guidelines and tips to Palestinians regarding water and sanitation services to reduce the risks of COVID-19. Advices and instructions are recommended to the residents and institutions about how to deal with the different water sources (i.e., network, tanker, and cistern), how to sterilize rooftop tanks, harvesting cisterns, and swimming pools as well as what disinfectants to use, how to make sure water supplies are clean and safe to drink, and how to safely treat and dispose wastewater (see PWA 2020). This is the only document published so far in the Palestinian territory to the best of the authors' knowledge.

The competent authorities are working now on several drafts, projects, and protocols to manage water and wastewater sectors after the COVID-19 pandemic. Service providers in the West Bank have made heightened procedures to curb the spread of the COVID-19 disease, yet, more consistent protocols are crucial for a better management of the sectors. As for the healthcare facilities in the West Bank, however, there have not been any new directives or procedures regarding the management of water supplies and wastewater services in response to the spread of COVID-19 virus yet. The United Nations Economic and Social Commission for Western Asia (UNESCWA) has several publications to assist Arab countries including Palestine mitigate the impacts of the COVID-19 pandemic (e.g., UNESCWA 2020).

In Palestine, we have to use up-to-date recommendations from the domestic epidemiological committee as well as to follow international, national and local policies, guidelines, and mandates concerning the COVID19 virus. Palestinians aim at reducing the risk of COVID-19 infection and the severity of the disease in their society. Promoting infection control in healthcare settings and other high-risk areas should be a top priority for competent authorities to protect staff, patients, and visitors at the same time.

As in many other countries, the authors urge local businesses and communities, on the other side, to take the pledge and every possible precaution necessary to protect against the spread of COVID-19. By taking the pledge, people commit to providing the hygiene of public environments and safeguarding the health of vulnerable populations. The cooperation and solidarity between all components in the Palestinian society, individuals and institutions, are strongly recommended to control and prevent the novel coronavirus disease. Palestinians need to take strong steps in key areas such as the healthcare facilities to fighting against the COVID-19 virus and providing a healthy and safe environment for their community.

\section{Conclusions and recommendations}

Proper management of medical wastes is currently of great importance to the Palestinians so that they can prevent serious environmental degradation. The aims of the present study are to evaluate water and sanitation services at the healthcare facilities in the West Bank of Palestine, and to re-evaluate the services after the onset of the novel coronavirus pandemic. The results of the PCBS and MoH (2014) represent the most recent data on the water and sanitation services at the healthcare facilities in the West Bank, and therefore, explain the existing condition as the pre COVID-19 status. However, the so-called new condition proposed to tackle the new comer is called the post-COVID-19 status. The current conditions of the water and sanitation services at healthcare facilities are assessed using the questionnaire, while the interviews are conducted to investigate changes made to the services provided during the COVID-19 pandemic. 
Since information from healthcare facilities was limited in the West Bank, qualitative and quantitative data from the year 2014 were collected and results were discussed and analyzed. A questionnaire study proved that medical waste management practices in healthcare facilities were not satisfactory, and therefore, particular attentiveness should be applied.

The study showed that $92.1 \%$ of the healthcare facilities in the West Bank were connected to public water networks in 2014, $12.9 \%$ of them purchased water tanks and $10.8 \%$ of them depended on harvested rainwater which may cause contamination and waterborne diseases. Outdated public water networks may result in possible contamination of water supplies. Water of unknown origin from tankers and cisterns might not comply with drinking water standards and users have to exercise extra caution. Water storage tanks on the rooftop of the healthcare facility have to be maintained clean and safe to use. Regardless the source of freshwater, the water quality has to be regularly examined and compared to local and international standards.

Out of the 495 healthcare facilities in the West Bank, $36.6 \%$ of them were connected to public wastewater networks and only $2.0 \%$ of them treated their wastewater in 2014. It can be simply said that most healthcare facilities existed in rural communities, leaving no choice for them to dispose their wastewater but cesspits. We can obviously state that there was no treatment to wastewater generated by healthcare facilities in 2014.

The Ministry of Health, among other regulatory institutions, has to make more stringent regulations to monitor and control the quality of wastewater discharged by healthcare facilities. The authors suggest granting permits to healthcare centers with proper infrastructure regarding wastewater services, establishing a sampling program for wastewater from healthcare facilities, setting a fine system for law offenders. Among all healthcare facilities in the West Bank, $29.6 \%$ of them got rid of wastewater using tight cesspits. Once these cesspits were filled off, wastewater was disposed into nearby valleys, and this would have adverse environmental impacts. This will cause pollution not only to air and soil, but also to surface water and groundwater, as well.

The fact that $33.8 \%$ of healthcare facilities utilized porous cesspits was more frightening as they definitely caused degradation to the soil and groundwater quality. Healthcare wastewater has to be appropriately discharged in treatment plants of medical wastewater for a safe disposal to the surrounding environment.
Water management strategies become greatly significant in healthcare facilities. Such strategies can be translated into national policies and standards that simultaneously lead to water conservation and maintain high quality water supplies. Proper healthcare wastewater management can protect both the public health and the environment in the West Bank. Water and wastewater management in healthcare facilities in the West Bank necessarily requires better cooperation and coordination among all involved competent authorities that share the responsibility of air, water, and land resources for a better quality of life to Palestinians.

To better understand how water and wastewater sectors are managed in the healthcare facilities after the coronavirus pandemic, personal interviews with experts from healthcare facilities, regulatory authorities, and service providers in the West Bank had been conducted. Service providers have made heightened procedures to curb the spread of the COVID-19 disease, yet, more consistent protocols are crucial for a better management of the sectors. As for the healthcare facilities, however, there have not been any new directives or procedures regarding the management of water supplies and wastewater services in response to the spread of COVID-19 virus yet.

Lessons from the international community experience fighting against the novel coronavirus should be learned and proper protocols have to be applied. Further investigations and studies are required to better understand the virus basics, characteristics, survival times, transmission pathways, etc. The decision makers of the health system in Palestine should not only make the proper regulations, they have to take quick and strict actions to address these new challenges added to the previous ones the system suffers from. The cooperation of all stakeholders, individuals, and institutions in the water and wastewater sectors at the healthcare facilities is strongly recommended to control and prevent the novel coronavirus disease.

Acknowledgments The authors would like to thank the staff of the PCBS and the $\mathrm{MoH}$ for the valuable efforts made in the joint survey study covering healthcare facilities in Palestine. The valuable information and thoughts given by interviewees from healthcare facilities, competent authorities, and service providers in the West Bank districts are highly acknowledged. The authors also acknowledge the insightful suggestions and comments of the handling editors and anonymous reviewers to improve the quality of this manuscript. 


\section{References}

Aish, A. M. (2013). Drinking water quality assessment of the middle governorate in the Gaza Strip, Palestine. Water Resources and Industry, 4, 13-20.

Ajo, P., Preis, S., Vornamo, T., Mänttäri, M., Kallioinen, M., \& Louhi-Kultanen, M. (2018). Hospital wastewater treatment with pilot-scale pulsed corona discharge for removal of pharmaceutical residues. Journal of Environmental Chemical Engineering, 6(2), 1569-1577.

Alazzeh, S., Galaitsi, S. E., Bishara, A., Al-Azraq, N., \& Durant, J. L. (2019). Impacts of intermittent water supply on water quality in two Palestinian refugee camps. Water, 11, 670 .

Al-Batsh, N., Al-Khatib, I. A., Ghannam, S., Anayah, F., Jodeh, S., Hanbali, G., Khalaf, B., \& van der Valk, M. (2019). Assessment of rainwater harvesting systems in poor rural communities: a case study from Yatta area, Palestine. Water, 11(3), 585.

Alimohammadi, M., Yousefi, M., Mayvan, F. A., Taghavimanesh, V., Navai, H., \& Mohammadi, A. A. (2018). Dataset on the knowledge, attitude and practices of biomedical wastes management among Neyshabur hospital's healthcare personnel. Data in Brief, 17, 1015-1019.

Almasi, A., Taghi, A. M., Mansoor, R., \& Ehsan, A. P. (2006). Water consumption, domestic wastewater generation and its biodegradability, based on monthly income and ambient temperature, in Kermanshah City. $2^{\text {nd }}$ International Conference on Water Resources and Arid Environments, 26-29 November 2006, King Saud University, represented by the Prince Sultan Research Center for Environment, Water and Desert, Riyadh.

Amnesty International. (2009). Troubled waters - Palestinians denied fair access to water: Israel-occupied Palestinian territories. London: Amnesty International Publications.

Anayah, F. M. (2006). An assessment of the nitrate and chloride in the West Bank groundwater resources using GIS. Master thesis. Nablus: An-Najah National University.

Anayah, F. M., \& Almasri, M. N. (2009). Trends and occurrences of nitrate in the groundwater of the West Bank, Palestine. Applied Geography, 29(4), 588-601.

Applied Research Institute - Jerusalem (ARIJ). (2015). Status of the environment in the state of Palestine. Bethlehem: ARIJ.

Azzi, L., Carcano, G., Gianfagna, F., Grossi, P., Gasperina, D. D., Genoni, A., Fasano, M., Sessa, F., Tettamanti, L., Carinci, F., Maurino, V., Rossi, A., Tagliabue, A., \& Baj, A. (2020). Saliva is a reliable tool to detect SARS-CoV-2. Journal of Infection, 81, e45-e50.

Baker, D. R., Barron, L., \& Kasprzyk-Hordern, B. (2014). Illicit and pharmaceutical drug consumption estimated via wastewater analysis. Part A: Chemical analysis and drug use estimates. Science of the Total Environment, 487, 629-641.

Bar-Or, I., Yaniv, K., Shagan, M., Ozer, E., Erster, O., Mendelson, E., et al. (2020). Regressing SARS-CoV-2 sewage measurements onto COVID-19 burden in the population: A proof-ofconcept for quantitative environmental surveillance. medRxiv, 1-11. https://doi org/10.1101 /2020.04.26.20073569.

Bhowmick, G. D., Dhar, D., Nath, D., Ghangrekar, M. M., Banerjee, R., Das, S., et al. (2020). Coronavirus disease
2019 (COVID-19) outbreak: Some serious consequences with urban and rural water cycle. NPJ Clean Water, 3, 32.

Bokhoree, C., Beeharry, Y., Makoondlall-Chadee, T., Doobah, T., \& Soomary, N. (2014). Assessment of environmental and health risks associated with the management of medical waste in Mauritius. APCBEE Procedia, 9, 36-41.

Boy-Roura, M., Mas-Pla, J., Petrovic, M., Gros, M., Soler, D., Brusi, D., \& Menció, A. (2018). Towards the understanding of antibiotic occurrence and transport in groundwater: Findings from the Baix Fluvià alluvial aquifer (NE Catalonia, Spain). Science of the Total Environment, 612, $1387-1406$

Daoud, A. K., Swaileh, K. M., Hussein, R. M., \& Matani, M. (2011). Quality assessment of roof-harvested rainwater in the West Bank, Palestinian authority. Journal of Water and Health, 9(3), 525-533.

European Environment Agency (EEA). (2014). Horizon (2020). Mediterranean report - Annex 5: Palestine. Technical report no 6/2014. Luxembourg: European Environment Agency.

Farkas, K., Hillary, L. S., Malham, S. K., McDonald, J. E., \& Jones, D. L. (2020). Wastewater and public health: the potential of wastewater surveillance for monitoring COVID-19. Current Opinion in Environmental Science \& Health, 17, 14-20.

Galus, M., Jeyaranjaan, J., Smith, E., Li, H., Metcalfe, C., \& Wilson, J. Y. (2013). Chronic effects of exposure to a pharmaceutical mixture and municipal wastewater in zebrafish. Aquatic Toxicology, 132, 212-222.

Hocquet, D., Muller, A., \& Bertrand, X. (2016). What happens in hospitals does not stay in hospitals: antibiotic-resistant bacteria in hospital wastewater systems. Journal of Hospital Infection, 93(4), 395-402.

Isidori, M., Lavorgna, M., Russo, C., Kundi, M., Žegura, B., Novak, M., \& Barceló, D. (2016). Chemical and toxicological characterisation of anticancer drugs in hospital and municipal wastewaters from Slovenia and Spain. Environmental Pollution, 219, 275-287.

Khan, N. A., Khan, K. A., \& Islam, M. (2012). Water and wastewater treatment using nano-technology. In L. Khemani, M. Srivastava, \& S. Srivastava (Eds.), Chemistry of phytopotentials: health, energy and environmental perspectives (pp. 315-318). Berlin: Springer.

Khan, N. A., Ullah Khan, S., Ahmed, S., Farooqi, I. H., Hussain, A., Vambol, S., \& Vambol, V. (2019). Smart ways of hospital wastewater management, regulatory standards and conventional treatment techniques: a short review. Smart and Sustainable Built Environment. https://doi.org/10.1108 /SASBE-06-2019-0079 ahead-of-print.

Khan, N. A., Ullah Khan, S., Ahmed, S., Farooqi, I. H., Yousefi, M., Mohammadi, A. A., et al. (2020). Recent trends in disposal and treatment technologies of emerging-pollutantsa critical review. Trends in Analytical Chemistry, 122, 115744.

Madhura, L., Singh, S., Kanchi, S., Sabela, M. I., Bisetty, K., \& Inamuddin, I. (2018). Nanotechnology based water quality management for wastewater treatment. Environmental Chemistry Letters, 17, 65-121. https://doi.org/10.1007 /s10311-018-0778-8.

Ministry of Health (MoH). (2013). Health annual report: Palestine 2012. Ramallah: Ministry of Health. 
Ministry of Health (MoH). (2016). National health strategy 20172022. Ramallah: Ministry of Health.

Ministry of Health (MoH). (2017). Health annual report: Palestine 2016. Ramallah: Ministry of Health.

Ministry of Health (MoH). (2019). Health annual report: Palestine 2018. Ramallah: Ministry of Health.

Nashashibi, M. (1995). Wastewater treatment strategies in Palestine. Master thesis. Delft: Institute of IHE.

Nashashibi, M., \& van Duiji, L. A. (1995). Wastewater characteristics in Palestine. Water Science and Technology, 32(11), 65-75.

Paleologos, E. K., O’Kelly, B. C., Tang, C., Cornell, K., Rodríguez-Chueca, J., Abuel-Naga, H., et al. (2020). Post Covid-19 water and waste water management to protect public health and geoenvironment. Environmental Geotechnics. https://doi.org/10.1680/jenge.20.00067.

Palestinian Central Bureau of Statistics \& Ministry of Health (PCBS \& MoH). (2014). Environmental survey for health facilities (governmental and non-governmental), 2014 Main findings. Ramallah: PCBS \& $\mathrm{MoH}$.

Palestinian Central Bureau of Statistics (PCBS). (2002). Wastewater treatment in the Palestinian territory 2002. Ramallah: PCBS.

Palestinian Central Bureau of Statistics (PCBS). (2012). Environmental survey for healthcare facilities (governmental and non-governmental). Ramallah: PCBS.

Palestinian Central Bureau of Statistics (PCBS). (2018). Preliminary results of the general census of population, housing and establishments 2017. Ramallah: PCBS.

Palestinian Water Authority (PWA). (2013a). National water and wastewater policy and strategy for Palestine: Toward building a Palestinian state from water perspective. Ramallah: Palestinian Water Authority.

Palestinian Water Authority (PWA). (2013b). Status report of water resources in the occupied state of Palestine-2012. Ramallah: Palestinian Water Authority.

Palestinian Water Authority (PWA). (2014). Water information system. Ramallah: Palestinian Water Authority.

Palestinian Water Authority (PWA). (2018). Annual report: Continuing achievements despite mounting challenges. Ramallah: Palestinian Water Authority.

Palestinian Water Authority (PWA). (2020). The novel coronavirus COVID-19: an educational guide for water and sanitation guidelines. Ramallah: Palestinian Water Authority.

Pfeiffer, M. V. (2001). Vulnerability and the international health response in the West Bank and Gaza Strip: An analysis of health and the health sector. Palestine: World Health Organization and Peacepath Consulting.

Proia, L., Anzil, A., Subirats, J., Borrego, C., Farrè, M., Llorca, M., Balcázar, J. L., \& Servais, P. (2018). Antibiotic resistance along an urban river impacted by treated wastewaters. Science of the Total Environment, 628-629, 453-466.

Ryan-Fogarty, Y., O'Regan, B., \& Moles, R. (2016). Greening healthcare: systematic implementation of environmental programmes in a university teaching hospital. Journal of Cleaner Production, 126, 248-259.

Sánchez, A. S., Cohim, E., \& Kalid, R. A. (2015). A review on physicochemical and microbiological contamination of roofharvested rainwater in urban areas. Sustainability of Water Quality and Ecology, 6, 119-137.
SHOPS Plus. (2018). Health trends in the Middle East and North Africa: a regional overview of health financing and the private health sector. Rockville: Abt Associates Inc..

Siggins, A., Burton, V., Ross, C., Lowe, H., \& Horswell, J. (2016). Effects of long-term greywater disposal on soil: a case study. Science of the Total Environment, 557, 627-635.

Sim, W. J., Kim, H. Y., Choi, S. D., Kwon, J. H., \& Oh, J. E. (2013). Evaluation of pharmaceuticals and personal care products with emphasis on anthelmintics in human sanitary waste, sewage, hospital wastewater, livestock wastewater and receiving water. Journal of Hazardous Materials, 248, 219-227.

Szekeres, E., Baricz, A., Chiriac, C. M., Farkas, A., Opris, O., Soran, M. L., \& Coman, C. (2017). Abundance of antibiotics, antibiotic resistance genes and bacterial community composition in wastewater effluents from different Romanian hospitals. Environmental Pollution, 225, 304-315.

United Nations (UN). (1997). Glossary of environment statistics. Studies in methods, Series F, No. 67. New York: UN.

United Nations Development Programme (UNDP). (2014). The 2014 Palestine human development report: Development for empowerment. Jerusalem: UNDP.

United Nations Economic, \& Social Commission for Western Asia (UNESCWA). (2020). Effects of the COVID-19 pandemic over the water-scarce Arab region. Policy brief. 5. Beirut: UNESCWA.

Wang, W., Xu, Y., Gao, R., Lu, R., Han, K., Wu, G., \& Tan, W. (2020). Detection of SARS-CoV-2 in different types of clinical specimens. Jama, 323(18), 1843-1844.

Water Sector Regulatory Council (WSRC). (2019). The establishment of the wastewater monitoring program. Ramallah: WSRC.

Weidhaas, J., Zachary Aanderud, Z., Roper, D., VanDerslice, J., Gaddis, E., Ostermiller, J., et al. (In review). Correlation of SARS-CoV-2 RNA in wastewater with COVID-19 disease burden in sewersheds. Nature. https://doi.org/10.21203/rs.3. rs-40452/v1.

Werner, C., Schlick, J., Witte, G., \& Hildebrandt, A. (2000). Ecosan closing the loop in wastewater management and sanitation. Eschborn: The Deutsche Gesellschaft für Internationale Zusammenarbeit (GIZ) GmbH.

Windfeld, E. S., \& Brooks, M. S. L. (2015). Medical waste management - A review. Journal of Environmental Management, 163, 98-108.

World Bank. (2016). West Bank and Gaza: Public expenditure review of the Palestinian Authority - towards enhanced public finance management and improved fiscal sustainability. Report no: ACS18454. Washington, DC: World Bank.

World Bank. (2018). Securing water for development in West Bank and Gaza. Washington, DC: World Bank.

World Health Organization (WHO). (2015). Water, sanitation and hygiene in health care facilities status in low-and middleincome countries and way forward. Geneva: WHO.

World Health Organization (WHO). (2017a). Achieving quality universal health coverage through better water, sanitation and hygiene services in health care facilities: a focus on Cambodia and Ethiopia. Geneva: WHO.

World Health Organization (WHO). (2017b). Safe management of wastes from health-care activities: a summary. Geneva: WHO. 
World Health Organization (WHO). (2018). Report on primary health care in the Eastern Mediterranean Region: review of progress over the last decade (2008-2). Cairo: World Health Organization Regional Office for the Eastern Mediterranean.

World Health Organization (WHO) \& United Nations Children's Fund (UNICEF). (2018). Core questions and indicators for monitoring WASH in health care facilities in the sustainable development goals. Geneva: WHO.

World Health Organization (WHO) \& United Nations Children's Fund (UNICEF). (2019). WASH in health care facilities: Global baseline report 2019. Geneva: WHO.
Xiao, F., Tang, M., Zheng, X., Liu, Y., Li, X., \& Shan, H. (2020). Evidence for gastrointestinal infection of SARS-CoV-2. Gastroenterology, 158(6), 1831-1833.

Yadav, M. K., Short, M. D., Aryal, R., Gerber, C., van den Akker, B., \& Saint, C. P. (2017). Occurrence of illicit drugs in water and wastewater and their removal during wastewater treatment. Water Research, 124, 713-727.

Publisher's note Springer Nature remains neutral with regard to jurisdictional claims in published maps and institutional affiliations. 